\title{
Challenges Encountered by the National High School Teachers in Doing Action Research
}

\author{
Leila J. Abelardo, Mary Ann A. Lomboy, Cora C. Lopez, Felipe E.Balaria, \\ Gener S.Subia
}

\begin{abstract}
This study was conducted in the First Semester of AY 2018-2019 to discuss the challenges encountered by the teachers of a National High School in Licab, Nueva Ecija in doing action research. The study revealed that the main challenges encountered by the teachers were: insufficient training and seminar on research; heavy teaching loads; lack of clear role of teachers in the school to conduct research; and busy on personal life. The following recommendations are hereby laid out: the teachers should be encouraged to pursue advance higher education and HEI's should include action research as part of their basic education curriculum so that the graduates will be knowledgeable about its processes even without pursuing advance higher education right away; the work load of teachers should be lightened to allow them enough time to conduct research. Likewise, the policy makers in the Department of Education may consider allotting a percentage of time for teachers to do research; since profile has no significant relationship with challenges a common research development plan may be considered for implementation in the school level. Echoing of seminars on research may also be considered; and the Department of Education should implement a more efficient system of communicating its research policies and programs down to the teachers' level.
\end{abstract}

Keywords- Action research, addressing research incapability, Department of Education Teachers, research challenges.

\section{INTRODUCTION}

Research is one of the keys to the development of any organizations. It is defined as a systematic process of collecting and analyzing data to increase the understanding of a topic [1]. In the field of Education, research refers to the systematic collection and analys is of data related to the field [2].

Action research is a type of research commonly used in an educational institution. Conducting action research is putting the action in operation. It means executing a proposed alternative strategy to collect systematically relevant data to find out how these work. It is also a way to discover how a particular practice can be improved or adjusted to address the educational problem and writing a narrative account of what happened [3]. Additionally, it is the process of studying a school situation to understand and improve the quality of the educative process [4].

The purpose of doing action research is to identify teachers and departments' concerns and problems, to be able to make accurate decisions given available information [5] and to recommend solutions based on the results and findings made [6] between the government and the communities. Further, it will develop the teachers' scientific research skills and capabilities [7] as cited by [8]. Action research is part of the teacher's annual appraisal as this promotes professional growth and development [6]. It comprises five percent of the total score in the individual performance commitment and review [6] form for teachers. Teachers may also use their finished research, specifically when it is adopted by the school and other schools, as part of their portfolio for future promotion. With this, it will positively contribute to the overall teacher and school performance as well.

However, teachers from elementary and secondary are uninterested and unmotivated in doing action research despite issuance of DepEd order no. 39 s 2016 or the adoption of the Basic Education Research Agenda which guides DepEd and stakeholders in the conduct of education research and the utilization of research results. Some reasons and challenges encountered by teachers on [9] doing research are tight teaching timetable and heavy teaching workload [10] and [11]. Teachers ignore the positive effect of researching their professional growth. They are not interested in researching because they perceive that it is an additional workload for them. 
The respondent national high school is a public school under the Schools Division of Nueva Ecija (SDO-NE) which is covered by the DepEd Order no. 39 s 2016. It is one of the oldest public high schools in Nueva Ecija and has 52 teaching force and eight (8) non-teaching personnel. Currently, it has no research output submitted to SDO-NE, thus resulting in non-compliance with DepEd order no. 39, s. 2016. However, the school sends one (1) up to three (3) teachers to the division and regional research trainings every year. After the training, the trained teachers would echo the seminar content to all the teaching personnel in the school, thru In-service or school-based training done every term break. As part of the school-based training, each teacher is required to submit a title of action research. However, only less than 50\% complied and no one ever finished research even in the past years.

The lack of research output of the teachers led to the conduct of this research as it aimed to determine challenges encountered by the teachers in doing action research. Likewise, since there is an evident gap in the pool of knowledge as evidenced by the inadequate quantity of studies conducted on teachers' challenges and desires towards undertaking action research, this paper was conceptualized; both to fill the gap and add to the pool of existing knowledge concerning researches in the public schools. The implication is for the school heads, policy makers, and DepEd officials to consider the findings to address the needs of the teachers.

This study specifically aimed to determine the profile of the teachers in terms of the following: 1.1 academic ranks, 1.2 highest educational attainments, 1.3 number of research output, and 1.4 number of trainings/seminars attended related to research. It also aimed to describe the challenges they encountered in doing action research. To determine the possible profile related causes of the challenges that the respondents have encountered the relationship between profile and challenges were also determined. Furthermore, the proponent also investigated the solutions that the respondents may suggest to address their challenges.

\section{METHODOLOGY}

This study utilized the descriptive research design in determining the challenges encountered by the respondents. According to [12], as cited by the authors in [13] and [14], descriptive research systematically describes a situation, problem, phenomenon, service or program, attitude toward an issue or simply, it provides information on a subject. All the 52 teachers in the respondent National High School in
Licab, Nueva Ecija were used as respondents. To gather the necessary research data, the questionnaire developed by [6] was modified, adapted and used. The modified instrument was content validated and tested for reliability by experts. The data were gathered using a questionnaire. The researchers sought oral permission from the respondents and school principal accompanied by a request letter. To ensure a $100 \%$ retrieval of the questionnaires, the researchers personally administered and retrieved the questionnaires from the respondents when accomplished. The data gathered from the first statement of the problem was analyzed and interpreted using frequency count and percentage; the data from the second question was analyzed and interpreted using weighted mean $(4.2-5.0$, A Very Big Challenge; 3.4 to 4.19 , Big Challenge; 2.6 to 3.39 , Fairly a Challenge; 1.8 to 2.59 , A Slight Challenge; 1.00 to 1.79, A Very Slight Challenge) while the data for the third question was analyzed and interpreted using appropriate correlation statistics through the aid of SPSS version 20.

\section{RESULTS AND DISCUSSIONS}

1. Profile of the Teachers/Respondents

Table 1 Academic Ranking

\begin{tabular}{|c|c|c|}
\hline $\begin{array}{c}\text { Academic } \\
\text { Ranking }\end{array}$ & No of. Teachers & Percentage \\
\hline Teacher I & 10 & $19.2 \%$ \\
\hline Teacher II & 11 & $21.2 \%$ \\
\hline Teacher III & 26 & $50 \%$ \\
\hline Master Teacher I & 4 & $7.7 \%$ \\
\hline Master Teacher II & 1 & $1.9 \%$ \\
\hline TOTAL & $\mathbf{5 2}$ & $\mathbf{1 0 0 \%}$ \\
\hline
\end{tabular}

In terms of academic rank. The study revealed that majority of the respondents were Teacher III, comprising 26 or $50 \%$, followed by Teacher II comprising 11 or $21.2 \%$, and by Teacher I, comprised by 10 or $19.2 \%$. There were only four or $7.7 \%$ of them who were Master Teacher I and only one or $1.9 \%$ who is Master Teacher II.

Table 2 Highest Educational Attainment

\begin{tabular}{|l|c|c|}
\hline $\begin{array}{c}\text { Highest } \\
\text { Educational } \\
\text { Attainment }\end{array}$ & No of. Teachers & Percentage \\
\hline Bachelor's degree & 9 & $17.3 \%$ \\
\hline $\begin{array}{l}\text { Earned units in } \\
\text { master's degree }\end{array}$ & 38 & $73.10 \%$ \\
\hline
\end{tabular}




\begin{tabular}{|l|l|l|}
\hline Master's degree & 3 & $5.8 \%$ \\
\hline $\begin{array}{l}\text { Earned units in a } \\
\text { doctoral degree }\end{array}$ & 2 & $3.8 \%$ \\
\hline \multicolumn{1}{|c|}{ TOTAL } & $\mathbf{5 2}$ & $\mathbf{1 0 0 \%}$ \\
\hline
\end{tabular}

In terms of highest educational Attainment. The study also revealed that majority of the respondents comprising 38 or $73.10 \%$ had earned units in a master's degree. The second majority, comprising nine (9) or $17.3 \%$ were plain graduates of Bachelor's degree. Only a handful of them have earned master's ( 3 or $5.8 \%$ ) and doctorate ( 2 or $3.8 \%$ ) degrees, indicating that the teachers were probably not capable enough of conducting research as the required research skills and capabilities can be developed through advance studies and can be enhanced by the confidence that having graduated from advance studies can give. However, the fact that there were also a few of them who have already acquired masters and doctorate and yet were not able to come up with single action research is alarming and a sign that indeed there may be problem hindering them from doing so.

Table 3 Number of Trainings/Seminars Attended

\begin{tabular}{|c|c|c|}
\hline $\begin{array}{c}\text { No. of Trainings } \\
\text { Attended }\end{array}$ & No of. Teachers & Percentage \\
\hline 0 & 43 & $82.7 \%$ \\
\hline 1 & 4 & $7.7 \%$ \\
\hline 2 & 1 & $1.9 \%$ \\
\hline 3 & 2 & $3.8 \%$ \\
\hline 4 & 1 & $1.9 \%$ \\
\hline 5 & 1 & $1.9 \%$ \\
\hline TOTAL & $\mathbf{5 2}$ & $\mathbf{1 0 0 \%}$ \\
\hline
\end{tabular}

In terms of Research, Related trainings attended. It was also found out in the study that a big majority of the respondents, comprising 43 or $82.7 \%$ have not attended any related research training in their entire professional life as teachers at all. There is a reason to believe, therefore that there is a tendency for teachers to have the low capability to conduct research and prepare research report because they lack exposure in terms of attendance to seminars.

Table 4 Research Output from 2016 to 2019

\begin{tabular}{|l|c|c|}
\hline \multicolumn{1}{|c|}{ Research Output } & $\begin{array}{c}\text { No. of } \\
\text { Teachers }\end{array}$ & Percentage \\
\hline $\begin{array}{l}\text { Action research produced } \\
\text { and submitted to DepEd }\end{array}$ & 0 & $0 \%$ \\
\hline Action research produced & 1 & $1.92 \%$ \\
\hline
\end{tabular}

\begin{tabular}{|l|c|c|}
\hline but did not submit to DepEd & & \\
\hline $\begin{array}{l}\text { Produced another/another } \\
\text { type/s of research for } \\
\text { graduate studies }\end{array}$ & 6 & $11.54 \%$ \\
\hline Action research is ongoing & 1 & $1.92 \%$ \\
\hline $\begin{array}{l}\text { Another type of research is } \\
\text { ongoing }\end{array}$ & 12 & $23.08 \%$ \\
\hline No research produced & 32 & $61.54 \%$ \\
\hline \multicolumn{1}{|c|}{ TOTAL } & $\mathbf{5 2}$ & $\mathbf{1 0 0 \%}$ \\
\hline
\end{tabular}

In terms of Research Outputs. The result of the study revealed that majority of the respondents, comprising 32 or $61.54 \%$ have not conducted any type or form of research at all, and it is alarming that none or zero (0) has conducted any action research at all, in spite of the issuance of DepEd Order No. 39 series of 2016 which requires them to submit or do action research as part of their obligation as teachers. This is a challenge to the Department of Education, particularly of the Schools Division of Nueva Ecija.

\section{Challenges Encountered by the teachers in Conducting Research}

When the responses of the teachers were analyzed it was found out that the challenges encountered by teachers on [9] action research writing can be categorized as related to 1) skill, 2) time, 3) motivation, 4) interest, and 5) support by the school administration.

It is interesting to note that among the five categories, Time- related factors took the lead with a weighted mean rating of 4.14 described as strongly agree and verbally interpreted as a Big Challenge. This implies that time is the factor that gets in the way of the teachers in terms of conducting research. According to them, they find doing research time consuming, and an additional task to their already big volumes of work as teachers. They believe it may negatively affect their teaching performance and may likewise interfere with their personal lives.

The second factor that they also found challenging was Skill-Related, which obtained a weighted mean of 3.77, verbally interpreted also as a Big Challenge. This means that they tend to find research a difficult task and that they do not have enough knowledge about its processes. Next to Skill-Related factor is Support-Related, which obtained a weighted mean rating of 3.19 , verbally interpreted as a Fairly a Challenge. This implies that they were not being compensated in doing research as well as feeling like they are not being given support to successfully do research. 
Meanwhile, Motivation-Related and Interest-Related factors which obtained weighted mean ratings of 2.38 and 2.02 respectively were considered only as a Slight Challenge by the respondents. This means that they may also be interested in doing research; they just don't feel the motivation to indulge.

Table 5 shows the detail about the teachers' responses.

Table 5 Categories of Challenges Encountered by the Teachers

\begin{tabular}{|c|c|c|}
\hline The Challenges & $\begin{array}{l}\text { Weighted } \\
\text { Mean }\end{array}$ & $\begin{array}{c}\text { Verbal } \\
\text { Description }\end{array}$ \\
\hline \multicolumn{3}{|l|}{ Skill-related } \\
\hline $\begin{array}{l}\text { 1. I do not have enough } \\
\text { knowledge in doing } \\
\text { action research }\end{array}$ & 2.60 & Challenge \\
\hline $\begin{array}{l}\text { 2. I find researching a } \\
\text { difficult task }\end{array}$ & 4.27 & $\begin{array}{l}\text { A Very Big } \\
\text { Challenge }\end{array}$ \\
\hline $\begin{array}{l}\text { 3. I have low } \\
\text { proficiency in English }\end{array}$ & 1.85 & $\begin{array}{c}\text { A Slight } \\
\text { Challenge }\end{array}$ \\
\hline $\begin{array}{l}\text { Average weighted } \\
\text { Mean }\end{array}$ & 3.77 & $\begin{array}{c}\text { Big } \\
\text { Challenge }\end{array}$ \\
\hline \multicolumn{3}{|l|}{ Time-related } \\
\hline $\begin{array}{l}\text { 1. I find researching } \\
\text { time-consuming. }\end{array}$ & 3.92 & $\begin{array}{c}\text { Big } \\
\text { Challenge }\end{array}$ \\
\hline $\begin{array}{l}\text { 2. I find researching as } \\
\text { additional work }\end{array}$ & 4.15 & $\begin{array}{c}\text { Big } \\
\text { Challenge }\end{array}$ \\
\hline $\begin{array}{l}\text { 3. I am so busy with my } \\
\text { teaching practice to do } \\
\text { research }\end{array}$ & 4.4 & $\begin{array}{l}\text { Biggest } \\
\text { Challenge }\end{array}$ \\
\hline $\begin{array}{l}\text { 4. I am so busy with my } \\
\text { personal life to do } \\
\text { research. }\end{array}$ & 3.96 & $\begin{array}{c}\text { Big } \\
\text { Challenge }\end{array}$ \\
\hline $\begin{array}{l}\text { 5. Heavy teaching load } \\
\text { affects the practice of } \\
\text { research }\end{array}$ & 4.25 & $\begin{array}{l}\text { Biggest } \\
\text { Challenge }\end{array}$ \\
\hline $\begin{array}{l}\text { Average weighted } \\
\text { Mean }\end{array}$ & 4.136 & $\begin{array}{c}\text { Big } \\
\text { Challenge }\end{array}$ \\
\hline \multicolumn{3}{|l|}{ Motivation-Related } \\
\hline $\begin{array}{l}1 . \text { I do not receive } \\
\text { encouragement from the } \\
\text { school to do research }\end{array}$ & 2.73 & $\begin{array}{l}\text { Fairly a } \\
\text { Challenge }\end{array}$ \\
\hline $\begin{array}{l}\text { 2. I have no interest to } \\
\text { research at all. }\end{array}$ & 2.00 & $\begin{array}{l}\text { A Slight } \\
\text { Challenge }\end{array}$ \\
\hline $\begin{array}{l}\text { 3. I am not motivated to } \\
\text { do research }\end{array}$ & 3.00 & $\begin{array}{c}\text { Fairly a } \\
\text { Challenge }\end{array}$ \\
\hline $\begin{array}{l}\text { 4. I do not see the } \\
\text { importance }\end{array}$ & 1.96 & $\begin{array}{l}\text { A Slight } \\
\text { Challenge }\end{array}$ \\
\hline
\end{tabular}

\begin{tabular}{|c|c|c|}
\hline researching my career & & \\
\hline $\begin{array}{lr}\text { T. There is a lack of } \\
\text { recognition } & \text { to } \\
\text { conducted } & \text { research } \\
\text { activities } & \end{array}$ & 2.23 & $\begin{array}{l}\text { A Slight } \\
\text { Challenge }\end{array}$ \\
\hline $\begin{array}{ll}\text { Average } & \text { weighted } \\
\text { Mean } & \end{array}$ & 2.384 & $\begin{array}{c}\text { A Slight } \\
\text { Challenge }\end{array}$ \\
\hline Interest-Related & & \\
\hline $\begin{array}{l}\text { 1. I am not interested in } \\
\text { reading the research, } \\
\text { books, journals, and } \\
\text { other types of } \\
\text { publications }\end{array}$ & 2.04 & Disagree \\
\hline $\begin{array}{l}\text { 2. I have no interest to } \\
\text { research at all. }\end{array}$ & 2 & $\begin{array}{l}\text { A Slight } \\
\text { Challenge }\end{array}$ \\
\hline $\begin{array}{l}\text { Average weighted } \\
\text { Mean }\end{array}$ & 2.02 & $\begin{array}{l}\text { A Slight } \\
\text { Challenge }\end{array}$ \\
\hline Support-related & & \\
\hline $\begin{array}{l}\text { 1. There are insufficient } \\
\text { reference materials } \\
\text { (journals, research } \\
\text { books, research reports, } \\
\text { etc.) in school/library. }\end{array}$ & 3.27 & $\begin{array}{l}\text { Fairly a } \\
\text { Challenge }\end{array}$ \\
\hline $\begin{array}{l}\text { 2. There are insufficient } \\
\text { training and seminar on } \\
\text { research. }\end{array}$ & 3.46 & $\begin{array}{l}\text { Fairly a } \\
\text { Challenge }\end{array}$ \\
\hline $\begin{array}{l}3 \text { There is insufficient } \\
\text { budget from DepEd } \\
\text { division office to } \\
\text { undertake research. }\end{array}$ & 2.37 & Disagree \\
\hline $\begin{array}{l}\text { 4. There is a lack of } \\
\text { clear role of teachers in } \\
\text { the school to conduct } \\
\text { research }\end{array}$ & 3. 67 & $\begin{array}{c}\text { Big } \\
\text { Challenge }\end{array}$ \\
\hline $\begin{array}{l}\text { Average weighted } \\
\text { Mean }\end{array}$ & 3.19 & $\begin{array}{c}\text { Fairly a } \\
\text { Challenge }\end{array}$ \\
\hline $\begin{array}{ll}\text { Overall weighted } \\
\text { Mean }\end{array}$ & 3.11 & $\begin{array}{c}\text { Fairly a } \\
\text { Challenge }\end{array}$ \\
\hline
\end{tabular}

Legend: 4.20 - 5.0, A Very Big Challenge; 3.40 to 4.19, Big Challenge; 2.60 to 3.39 , Fairly a Challenge; 1.80 to 2.59 , A Slight Challenge; 1.00 to 1.79, A Very Slight Challenge

\section{Relationship between Profile and Challenges}

Below is the table showing the details about statistical computation concerning the relationship between profile and challenges. 
Table 6 Relationship between Profile variables and Challenges

\begin{tabular}{|l|c|c|l|}
\hline \multicolumn{2}{|l|}{ Challenges Encountered } \\
\hline Profile variables & $\begin{array}{c}\boldsymbol{r} \text { - } \\
\text { value }\end{array}$ & $\begin{array}{c}\text { p- } \\
\text { value }\end{array}$ & Interpretation \\
\hline Academic Rank & -.155 & .272 & $\begin{array}{l}\text { No significant } \\
\text { relationship }\end{array}$ \\
\hline $\begin{array}{l}\text { Highest } \\
\text { Educational } \\
\text { Attainment }\end{array}$ & -.029 & .836 & $\begin{array}{l}\text { No significant } \\
\text { relationship }\end{array}$ \\
\hline $\begin{array}{l}\text { Number of } \\
\text { Research Output }\end{array}$ & -.019 & .895 & $\begin{array}{l}\text { No significant } \\
\text { relationship }\end{array}$ \\
\hline $\begin{array}{l}\text { Number of } \\
\text { Trainings/ } \\
\text { Seminars }\end{array}$ & -.100 & .483 & $\begin{array}{l}\text { No significant } \\
\text { relationship }\end{array}$ \\
\hline
\end{tabular}

*correlation is significant @0.05 level

When the profile data and research challenges were subjected to statistical analysis, it was found out that there was no significant relationship found between variables at all. This finding indicates that profile variables cannot be an indicator of the challenges that the teachers perceived regarding the conduct of action research or vice versa, challenges cannot be indicated by the profile of the respondents.

\section{CONCLUSIONS AND RECOMMENDATIONS}

This study purported to determine the challenges hindering teachers from implementing action research, the relationship between profile variables and challenges encountered, and the suggestions that teachers may offer to avert the challenges. Using descriptive research, survey instrument and guided interview for data gathering and 52 respondent teachers from the subject school, the following findings were arrived at: 1) Majority of the teachers had academic rank of Teacher 3; with bachelor's degree and units in masters level as highest educational attainment, with no training about doing action research at all. They are also bachelor's degree graduate and barely have master's degree unit and never had conducted action research at all; 2) The primary challenge encountered by the teachers in conducting research was time and skill-related as well as the absence of support; 3) There was no significant relationship found between any profile variables and challenges at all; and 4) The suggested solutions of the teachers implied that they were seemingly not aware of the DepEd's effort to cultivate action research capability building in the field.
With the foregoing, the following recommendations are hereby laid out: 1) The teachers should be encouraged to pursue advance higher education and HEI's should include action research as part of their basic education curriculum so that the graduates will be knowledgeable about their processes even without pursuing advance higher education right away; 2) The work load of teachers should be lightened to allow them enough time to conduct research. Likewise, the policy makers in the Department of Education may consider allotting a percentage of time for teachers to do research; 3) since profile has no significant relationship with challenges, a common research development plan may be considered for implementation in the school level. Echoing of seminars on research may also be considered;4) the Department of Education should implement a more efficient system of communicating its research policies and programs down to the teachers ' level; and 5) Experts should educate teachers on how to conduct a direct and simple [15] way of doing an action research.

\section{REFERENCES}

[1] Dep.Ed.(2016). Adoption of the Basic Education Research Agenda. www.deped.gov.ph.depEd order no. 39 s. 2016.

[2] ates, Lyn (2004). What Does Good Educational Research Look Like? : Situating a Field and Its Practices. Conducting Educational Research. McGraw-Hill International. ISBN 978-0-335-2199-9

[3] Bayan, Mary Finela M. Bayan.The Importance of Action Research in Education.Deped-Nueva Ecija.net.March 6, 2017

[4] Johnson, A.P.(2012). A short guide to action research (4 ${ }^{\text {th }}$ ed). New Jersey: Pearson Education.

[5] Subia, Gener S. (2018). Think Like My Teacher (TLMT): A New Method in Assessing Millennial Learners. International Journal of Arts, Humanities and Social Sciences.Volume 3. Issue 1.www.ijahss.com. pp. 57-61.

[6] Ula, Mark B., Barrera, Kenneth Ian B., Acompanado Meller M. Philippine Classroom Teachers as Researchers: Teachers' Perceptions, Motivations, and Challenges. Australian Journal of Teacher Education. Vol 42 issue 11 Article 4. 2017

[7] Alvarado, F., Leon, M., Colon, A.(2016). DesignAnd validation of a questionnaire to measure researchskills: experience with engineering students. Journalof Technology and Science Education [Online]. 6(3),pp 219-233. http://dx.doi.org/10.3926/jotse.227.

[8] Subia, G., Florencondia, N., Trajano,M.,Gutierrez, M., Zabala, B.Jr.(2018). Factors Associated with the Research Paper Writing Capabilities of Engineering Management and Vocational Technological Education Freshman Students. International Journal for Research \& 
Development in Technology. Volume 9, Issue 3. ISSN (O):-23493585.

[9] Subia,G.,Lepon, M., Cumbe, M., Marcos, M.I., Cruz, J. (2018).Vocational Technological Education Teachers on Facing Challenges of the Restructured Curriculum. Saudi Journal of Engineering and Technology(SJEAT).Volume-3, Issue-4, pp.198-203. DOI:10.21276/sjeat.2018.3.4.1

[10] Morales, M.P.E. (2016). Participatory action research $(P A R)$ cum action research $(A R)$ in teacher professional development: A literature review. International Journal of Research in Education and Science (IJRES), 2(1), 156-165.

[11] Kutlay, N. (2012). A survey of English language teachers' views of research. Procedia - Social and Behavioral Sciences. 70, 188-206.

[12] Kumar, R.(2014). Research Methodology: A step-by-step guide for beginners (4th.ed.) SAGE,CA: Thousand Oaks.

[13] Pagandian, Joni L. and Eduardo, Jesster P.Restorative Justice in Cordillera Administrative Regio: tradition and Praxis towards a Peace Process Model. International Journal of Social Science Studies.Vol.7, No.1; January 2019. Doi:10.11114/ijsss.v7il.3748.

[14] Subia, G.S., Trinidad, C.L., Pascual, R.R., Medrano, H.B. \& Manuzon, E.P.(2019). Learning Styles and Preferred Teaching Styles of Master of Arts in Teaching (MAT), major in Vocational Technological Education (VTE) Generation Y Learners. International Journal of English Literature and Social Sciences (IJELS) .Vol-4, Issue 2, MarApr, 2019. https://dx.doi.org/10.22161/ijels.4.2.35.

[15] Subia, G.S.(2018). Comprehensible Technique in Solving Consecutive Number Problems in Algebra. Journal of Applied Mathematics and Physics, 6, 447-457. https://doi.org/10.4236/jamp.2018.63041 